\title{
Role of the hippocampus in memory functioning: modern view
}

\author{
D. O. Assonov, B. S. Bozhuk \\ Bogomolets National Medical University, Kyiv, Ukraine
}

The purpose of this review was to develop the comprehensive conception of the hippocampus role in the functioning of human memory, based on data obtained by analysis of the latest scientific literature on the topic and make recommendations for further ways of researches in this topic. The scientific literature of the last 5 years on the role of the hippocampus in memory functioning was analyzed.

Based on the reviewed literature, we made the next conclusions: the hippocampus is an extremely important for memory structure with various connections for different types of memory; the hippocampus is affected by a variety of substances, most studied now are glucocorticosteroids, whose effect on memory differs depending on the start time of action; the hippocampus volume in mental disorders affecting memory is less than normal, which makes it an important diagnostic criterion; at the moment, various promising methods that can help in the therapy of PTSD, depression, phobias and other disorders associated with memory impairment and based on the knowledge of the hippocampus for the treatment of memory disorders are being developed. Based on these conclusions and data, which were analyzed, we offered the following recommendations: to implement the hippocampal function examination in the diagnostics of mental disorders, which are accompanied by a violation of its work; to use the size of the hippocampus as one of the prognostic factors for the severity of the memory-associated disorders and the therapy progress; to carefully investigate the difference in the effect of various psychotherapies and pharmacotherapies on the hippocampus to determine exactly which of the therapies is the most morphologically reasonable; to find out how significant the decrease in the hippocampal volume is for the memory functioning; to use pathogenetically and morphologically based methods to improve the function of the hippocampus in the treatment of disorders that are accompanied by memory problems.

\section{Роль гіпокампа в роботі пам'яті: сучасний погляд}

\section{А. О. Ассонов, Б. С. Божук}

Мета роботи - розробити всебічну концепцію ролі гіпокампа у функціонуванні пам'яті людини на основі даних, що отримані під час аналізу новітньої наукової літератури з цієї теми, а також виробити рекомендації для дальших досліджень у цій області. Аналізувалась наукова література останніх 5 років про роль гіпокампа у функціонуванні пам'яті.

Висновки. Гіпокамп є дуже важливою структурою пам'яті зі зв'язками, які відрізняються для різних типів пам'яті. На гіпокамп впливають різні речовини, найбільш вивченими серед них нині є глюкокортикостероїди, дія яких на пам'ять відрізняється залежно від часу початку їхньої дії. Розмір гіпокампа при психічних розладах, що впливають на пам'ять, менше норми, що робить його важливим діагностичним критерієм. Зараз розробляються різні перспективні методи, що можуть допомогти в терапії посттравматичного стресового розладу, депресії, фобій та інших розладів, котрі пов'язані з погіршенням пам'яті та засновані на знанні гіпокампа для лікування розладів пам'яті. На підставі цих висновків і даних, що проаналізовані, запропонували рекомендації: ввести дослідження функції гіпокампа в тактики діагностики психічних розладів, що можуть супроводжуватись порушенням його роботи; використовувати розмір гіпокампа як один із прогностичних факторів важкості перебігу пов'язаних із пам'яттю розладів і ходу терапії; ретельно досліджувати різницю у впливі різних психо- та фармакотерапій на гіпокамп, щоб точно сказати, яка з терапій морфологічно доцільна; з'ясувати, наскільки значущим є зменшення обсягу гіпокампа для функціонування пам'яті; використовувати патогенетично та морфологічно обґрунтовані методи для поліпшення функції гіпокампа при лікуванні розладів, що супроводжуються проблемами пам'яті.

\section{Роль гиппокампа в работе памяти: современный взгляд}

\section{А. А. Ассонов, Б. С. Божук}

Цель работы - разработать всестороннюю концепцию роли гиппокампа в функционировании памяти человека на основе данных, полученных при анализе новейшей научной литературы по данной теме и выработать рекомендации для дальнейших исследований в этой области. Анализировалась научная литература последних 5 лет о роли гиппокампа в функционировании памяти.

Выводы. Гиппокамп - необычайно важная для памяти структура со связями, различающимися для разных типов памяти. На гиппокамп влияют различные вещества, наиболее изученными среди них сейчас являются глюкокортикостероиды, действие которых на память различается в зависимости от времени начала их действия. Размер гиппокампа при психических расстройствах, влияющих на память, меньше нормы, что делает его важным диагностическим критерием; в настоящее время разрабатываются различные перспективные методы, которые могут помочь в терапии посттравматического стрессового расстройства, депрессии, фобий и других расстройств, связанных с ухудшением памяти и основанных на знании гиппокампа для лечения расстройств памяти. На основе этих выводов и данных, которые были проанализированы, мы предложили следующие рекомендации: ввести исследование функции гиппокампа в тактики диагностики психических расстройств, которые могут сопровождаться нарушением его работы; использовать размер гиппокампа как один из прогностических фракторов тяжести течения связанных с памятью расстройств и хода терапии;

Ключові слова: гіпокамп, пам'ять, глюкокортикоїаи, психічні захворювання.

Запорізький медичний журнал. - 2017. T. 19, № 6(105). C. $833-838$ 
тщательно исследовать разницу во влиянии различных психотерапий и фармакотерапий на гиппокамп, чтобы точно сказать, какая из терапий наиболее морфологически разумна; выяснить, насколько значительным является уменьшение объема гиппокампа для функционирования памяти; использовать патогенетически и морфологически обоснованные методы для улучшения функции гиппокампа при лечении расстройств, сопровождающихся проблемами памяти.

In 1957, William Beecher Scoville and Brenda Milner described for the first time patients who after bilateral resection of hippocampal complex observed persistent deviation of recent memory in the form of anterograde and some retrograde amnesia, but with early memories and technical skills saved [22]. Then the authors made an important conclusion that the hippocampus is involved in the human memory, especially in the retention of current experience. From that moment it was began the active research of the hippocampal role in memory functioning and was accumulated a lot of knowledge about its work and made many conclusions. Today it is one of the most studied brain structures in neuroscience [26]. Its exceptional role in neuroscience confirms that Nobel Prize 2014 in Physiology or Medicine was awarded to John O'Keefe, May-Britt and Edvard I. Moser for researches related to the work of the hippocampus.

Recently, there were only confirmed the crucial importance of the hippocampus in encoding and consolidation of memory. In recent years, many researchers demonstrated that the hippocampus plays an important role not in a single type of memory, but it is necessary for normal functioning of various types of memory, and it is known that it is important for the following types: spatial [14,19], episodic [19], motor, verbal [11], social [17] memory. However, many questions about its role in the functioning of memory remain unanswered. New researches aimed at finding answers to these questions give a large amount of material for analysis and a lot of new knowledge, but the rate of knowledge accumulation and its multiplicity makes it quite often fragmented, thus there is still no complete picture of the hippocampus functioning.

In this article, we attempt to summarize some latest knowledge about hippocampus role in the functioning of memory and to get a bit closer to forming a complete picture of its work in this area, based on data from new studies, in order to develop recommendations for the integration of this picture into the clinical practice and to suggest some perspectives of treatment that will be based on this picture.

\section{Purpose}

Development of the comprehensive conception of the hippocampus role in the functioning of human memory, based on data obtained by analysis of the latest scientific literature on the topic and make recommendations for further ways ofresearches in this topic, based on developed conception.

Tasks. To achieve the purpose of this study, we should perform a number of tasks:

1. To analyze scientific literature of recent years describing various aspects of the hippocampus role in memory functioning and based on these data potential new treatments for disorders associated with loss or negative memories or intrusive memories.

2. To organize the information we found in the literature, compare conflicting opinions about various aspects of the hippocampus work in memory functioning.

3. To consolidate the data in a coherent picture of the hip- pocampus role in memory formation, based on the given sources and processed information.

4. To develop recommendations for the integration of this picture into clinical practice and to suggest perspectives of treatment that will be based on this picture.

5. To identify issues, which were not covered by the study, but can potentially supplement the results and continue the discussion.

\section{Materials and methods}

The scientific literature within last 5 years on the role of the hippocampus in memory functioning was analyzed. Publications from previous years were taken into account in the absence of new research in this area or authors are recognized by experts on the subject and conclusions have not lost relevance. During searching we used scientometric and bibliographic databases as Google Scholar, PubMed, Scopus, ScienceDirect.

\section{Results and Discussion}

We realized that it is impossible to cover all the latest research on the hippocampus role in memory functioning in one review, so we decided to focus on the most interesting and potentially important, in our view, aspects. For convenience and structuring of the article we divided reviewed studies into several content blocks.

Connections of the hippocampus with other brain areas. Since the discovery of the hippocampus role in memory functions multiple researches accumulated enough data so that we can confidently say that the hippocampus is not the only brain structure that implicated in the memory operations and that these structures are not isolated from each other, they act together. However, the results of different studies are currently not united into an integrated system, so there is still absent complete picture of the hippocampus functional connections with other brain areas and systems. Also there is little available data about all the mechanisms of each linked to hippocampal structures. Here we review recent studies devoted to the relationship of the hippocampus with other brain structures and make an attempt to combine distinguished data into more complete picture.

Although besides the hippocampus functioning in the memory other brain regions take part also such as frontal and parietal regions [8], we still know little about their functional interaction with hippocampus during the memory formation and their role.

In recent years an interesting hypothesis about the relationship of the left hippocampus with other structures of the left hemisphere has appeared. Krogh et al. (2014) found association between verbal memory performance and left hippocampal volume (previously there were no specifically related to left or right hippocampus associations) and supposed that their finding may integrate into the conception of speech production predominantly being situated in the left brain hemisphere [9]. For us this study is interesting be- 
cause we can suggest that if left hippocampus in addition to the memory processes involved in speech production, this may explain the known impact of pronunciation of material aloud to memorization of this material. Artificial strengthening of work exactly of the left hippocampus and associated with it improvement of verbal memorization will be important in learning, related to remembering texts, as well as in the treatment of memory-dysfunction associated disorders.

There are also the studies that demonstrate us the functional connection between hippocampus and brain cortex that is fundamental for memory. In 2013 Tanaka et al. showed that silencing previously active CA1 hippocampal neurons prevents reactivation in cortical regions (subiculum, lateral entorhinal cortex, perirhinal cortex, retrosplenial cortex) that are important for context memory [24]. Thus hippocampus is important for memory also because can reinstate patterns of cortical activity that were observed during learning [24].

Backus et al. (2016) suppose that enhanced theta coupling between hippocampus and medial prefrontal cortex (mPFC) predicts successful memory integration [1]. They have found that theta oscillations orchestrate the integration of memories by engaging the hippocampus and facilitating communication between hippocampus and medial prefrontal cortex, constituting the first step in the formation of relational memory networks, enabling us to assimilate information [1].

Robin et al. (2015) examined functional connectivity of the hippocampus with the rest of the brain during spatial and episodic memory functioning and found that medial prefrontal-parietal network and a medial temporal lobe network functionally connected to the prefrontal and hippocampal seeds during episodic and spatial memory tasks. These two networks were functionally connected with one another during episodic memory task, but not during spatial memory tasks, that supports the hypothesis that episodic and spatial memory share a common medial temporal lobe-based neural substrate with episodic memory requires prefrontal subnetworks [19]. Besides the fact of functional connectivity between hippocampus and other brain regions and networks, this study shows that in the functioning of memory different types there are involved various functional connections.

Mello-Carpes and Ivan Izquierdo (2013) suppose that activation of Nucleus of the Solitary Tract-Nucleus Paragigantocellularis-Locus coeruleus-CA1 region of dorsal hippocampus pathway is related to the presentation of a novelty, which promotes an alert state and stimulates peripheral arousal and is important for object recognition memory [13].

Thus, recent studies reveal a little the network of brain regions associated with the hippocampus in the formation of memories. The hippocampus during its work has functional relations with cortical and subcortical structures: subiculum, lateral entorhinal cortex, perirhinal cortex, retrosplenial cortex, medial prefrontal cortex, Nucleus of the Solitary Tract, Nucleus Paragigantocellularis, Locus coeruleus. We assume that these sites are not the only ones hippocampal connected, and that functional hippocampal network is much bigger. Particularly interesting and promising in our opinion are researches aimed at differentiating the roles of different structures and their interconnections in different types of memory. This is crucial for therapy, because correct interference in the work of these structures will allow us to achieve our goals - to consolidate memories, improve memorization or disposed of unnecessary painful memories.
Molecular basis of hippocampus memory function. Cascades of chemical processes that occur in the hippocampus during memorization or recollection something is material substratum of human memory. Knowledge of the biochemical basis of the hippocampus memory-related operations has extremely important significance, because this knowledge will help in the future to return and improve memory in the patients with diseases related to its loss (e.g., Alzheimer's disease, brain injuries), or block access to some memories or permanently get rid of them at all (for example, during the treatment of phobias, post-traumatic stress disorders, some acute reactions to stress, depression, etc.). Here we review the data from recent studies on the molecular basis of hippocampus memory function and make an attempt to consolidate them and make some conclusions.

Stress activates the hypothalamus-pituitary-adrenal axis, which leads to the release of glucocorticoid hormones (mainly cortisol in humans) [4]. The hippocampus is one of the brain regions with the highest density of receptors for glucocorticoids, suggesting that this area is especially sensitive to stress [21]. The opinion that acute stress only reduces memory functioning wasn't right, as there wasn't the opinion that stress or glucocorticoids just facilitates memory formation. In fact, studies, held for the last years, showed that stress has not a single effect on hippocampus - it can enhance or impair hippocampal functioning, depending on the timing of stressor. Before learning stress (or glucocorticoid injection) may enhance memory (when it occurs within the context of a learning experience, shortly before or during learning), and impair memory when it occurs out of learning context [21]. It is also known that exposure to severe acute or chronic stress leads to dendritic atrophy in the CA1, CA3, dentate gyrus and loss of excitatory synapses $n$ the $C A 3$ area and some researchers suppose glucocorticoids can contribute to the severe or chronic stress negative effect on hippocampal-dependent memories [5].

Morrone Parfitt et al. (2012) showed that $\beta$-adrenergic receptors are involved in stress enhancement of long-term memory persistence [15]. Later Mello-Carpes et al. (2016) endorse this result and showed that hippocampal norepinephrine acting on $ß$-adrenergic receptors is essential also for object recognition memory consolidation [12]. Its release depends on Nucleus of the Solitary Tract-Nucleus Paragigantocellularis-Locus coeruleus-CA1 region of dorsal hippocampus pathway has been mentioned earlier [13].

Besides ß-noradrenergic mechanisms there is also hippocampal mechanisms mediated by brain-derived neurotrophic factor are important for the persistence of fear-motivated long-term memory and object recognition memory [2,12].

Thus, in recent years there mostly have been investigated steroids and norepinephrine. An important fact is that it had been advanced knowledge of the mechanisms and features of corticosteroids action on memory during stress. Currently we have a more complete picture of their impact, which will allow more accurate planning of psychopharmacological research tools. In general, we believe that knowledge of the norepinephrine and corticosteroids effect on memory is of paramount importance for the pharmacotherapy of memory disorders. In the appropriate section we review this in more detail. 
Hippocampus in some memory affecting mental disorders: recent discoveries. The hippocampus may be damaged not only by organic lesions. There are many mental disorders and diseases, associated with hippocampal memory dysfunction. As it is not possible to review them all in one article, we focused on fairly common disorders associated with the hippocampus dysfunction: post-traumatic stress disorder, depression and phobias. Moreover, we guess that a struggle with these disorders is of particular importance for Ukraine especially in light of the war in Donbass, the situation of displaced persons and economic crisis. We believe that the analysis of recent studies of the hippocampus can give useful information and recommendations for the treatment of that associated with memory disorders.

In recent years it has been appeared an assumption that hippocampal volume reductions are associated with post-traumatic stress disorder. Levy-Gigi, Richter-Levin, Szabo and Keri (2015) show that overgeneralization of negative context in people with post-traumatic stress disorder (PTSD) significantly correlated with hippocampal volume and conclude that reduced hippocampal volume may account for the difficulty of people with PTSD to differentiate negative and novel conditions, and thus may facilitate reexperiencing symptoms [10]. But there was strictly unclear, whether the reduced hippocampal volume is a result of PTSD or, maybe, a risk factor. The findings of Van Rooij et al. (2015) suggest that a smaller hippocampus is not the result of stress or trauma exposure, but a constitutional risk factor for the PTSD persistence [25]. Also in their study hippocampal volume has not been increased in patient with successful treatment [25]. As a counterweight, Zoladz and Diamond (2015) during their literature review found reports not only about smaller hippocampal volume and impaired hippocampus-dependent memory in patients with PTSD, but also multiple reports about absence of a hippocampal functioning global impairment in PTSD [27]. Therefore, since there were studies that confirmed the diametrically opposite points of view, Nelson and Tumpap (2016) made a meta-analytic study. As a result of 37 studies analysis two important conclusions have been found. The first is that PTSD is associated with significant bilateral reduction of the hippocampus, and the second is that increased PTSD symptom severity is significantly associated with reduced left hippocampal volume [16]. In addition to this, Rubin et al. (2016) found that greater hippocampal volume may predict better prognosis when facing exposure to a traumatic event and better outcome of exposure-based PTSD treatments [20]. We suppose that this correlation has an important prognostic value for outcome of patients with PTSD, giving to the doctor all grounds to suppose the potential level of PTSD severity. Also these findings may be useful for psychodiagnostics and prophylactics: diagnostics of hippocampal size can provide important information about the risk of PTSD occurrence in extreme situation. This information can be used in the selection of personnel in the military, police structures, emergency psychologists, etc.

Similar results were found during the phobia and panic symptoms researches. Reinecke et al. (2014) found that larger pre-treatment (right) hippocampal gray matter volume was predictive of greater reduction in panic symptom severity during cognitive-behavioral therapy [18]. Results of
Irle et al. (2010) research indicated reduced (right) hippocampal size in patients with generalized social phobia. The smaller hippocampal volumes were in individuals, the more severe disorder they had [6]. As authors claim, none of their patients received neither psychopharmacologic nor psychotherapeutic treatment at the time of assessment and patients with comorbid PTSD and depression were excluded [6]. Thus the results may show the hippocampal volume in generalized social phobia patients without other hippocampal size-reduction associated disorders.

It is well-known, that depression is also associated with hippocampal volume reduction [3]. But in recent years there were interesting findings, such as report about that an aerobic exercise intervention for outpatients with major depression does not increase hippocampal volume [9]. These findings are similar to that during PTSD treatment we described. Opposite to that findings Mahar, Bambico, Mechawar and Nobrega (2014), basing on the results of several studies, remarked in their review, that antidepressant treatment may increase hippocampal neurogenesis (possibly by increasing the monoaminergic neurotransmission) that was suppressed because of depression and chronic stress [11].

Thus, we think that one of the important discoveries of the recent years is that hippocampal volume supposed to be a constitutional prognostic factor: reduced hippocampal volume predicts higher disorder symptoms severity and larger pre-treatment hippocampus predicts milder symptoms severity and better outcome during therapy. We suppose that this is somehow connected with properties of memory systems, because all reviewed disorders (PTSD, depression, phobias) affect memory in that or other way: during PTSD patient re-experience traumatic events, during depression he has irrational cognitive distortions of his memories, during phobias traumatic experience often is the etiological factor. Further researches on this problem can present us useful information about which memory properties are affected in decreased hippocampus and can provide new ways of treatment.

Treatment that enhance hippocampal memory function. While some researchers are trying to obtain theoretical data that can help in memory treatment in future, other finding the ways of treatment, based on technologies and knowledge we have now. Latest researches show interesting results about brain stimulation (DBS) of hippocampus. Some groups of scientists have found that deep brain stimulation DBS may enhance learning and memory [23]. They claim that implications of such enhancement to patients affected with disorders of memory, such as Alzheimer's disease, may be of great significance. Backus et al. (2016) suppose that their findings about hippocampus-mPFC theta coupling might guide future attempts to increase memory integration by manipulating or entraining region-specific theta oscillations. They see in this the potential way to accelerate learning and enhance knowledge acquisition [1]. Suthana and Fried (2014) proposed future directions in neuroenhancement of memory, such as controllable DBS systems that provide on-demand stimulation during periods of critical information processing instead of continuous stimulation and using non-invasive electrical stimulation methods including transcranial magnetic stimulation (TMS) and transcranial direct current stimulation [23]. But there are several impediments to implementation of DBS as memory 
enhancing method. Jacobs et al. (2016) findings differ from Suthana and other researchers. They found that DBS at $50 \mathrm{~Hz}$ in this area significantly impairs spatial and verbal memory encoding and suggests that dynamic, responsive protocols are necessary for hippocampal DBS to improve memory [7]. Other issues that remain involve whether DBS application should be provided unilaterally or bilaterally, and the characterization of the precise effects of DBS at anterior versus posterior hippocampus due to its diverse functional anatomy with heterogeneous neurons [23,7]. Kim, Ekstrom and Tandon have some interesting point of view (2016): they suggest approaches to reliably stimulation to enhance or disrupt memory; a network-level modulation of coherence is likely to be more effective than individual nodes stimulation (stimulating single hippocampus for example) in the memory network [8]. All of this suggests that DBS is a potentially useful method of influence on the hippocampus to improve memory, but it needs to be expanded and further researches must be held before DBS-based memory enhance methods can be introduced into clinical practice.

Glucocorticoid-based drugs in memory-impairing disorders treatment may also be potentially useful. As it was mentioned earlier, glucocorticoid exposure around the time of learning seems to enhance memory, whereas such exposure out of the learning context impairs memory consolidation [4]. De Quervain, Schwabe and Roozendaal (2017) say that this is important to consider when designing clinical drugs: drug administration after defining memory phase should be targeted by glucocorticoid drugs has to be well timed to get the desired effect instead of opposite [4]. They also reviewed the clinical studies of glucocorticoid-based drugs and say that acute administration of glucocorticoids can have similar effects on memory processes in both acute and chronic stress conditions and that glucocorticoids-based interventions can be used in various neurological and psychotherapeutic areas, such as therapy of fear-related disorders, reducing retrieval of flashbacks in PTSD, during the extinction-based psychotherapy [4].

Thus, the potential strategies for the hippocampus mnemonic function improvement already exist, which can be used in the near future.

\section{Conclusions}

So, based on the reviewed literature, we can take responsibility to make the following conclusions:

1. The hippocampus is an unusually important memory structure with a huge network of functional connections with other structures of the central nervous system, and these connections are various for different types of memory.

2. The hippocampus is affected by a variety of substances. The most studied now are glucocorticosteroids, whose effect on memory differs depending on the start time of action. They also have perspective as drugs that improve memorization.

3. The hippocampus volume in mental disorders affecting memory is less than normal, which makes it an important diagnostic criterion.

4. At the moment, various promising methods based on the knowledge of the hippocampus for the treatment of memory disorders are being developed. Their development will help in the therapy of PTSD, depression, phobias and other disorders associated with memory impairment.

Based on what we discussed earlier, as well as on the conclusions, we can offer the following recommendations for clinical and theoretical neuroscience development:

1. To implement the hippocampal function examination in the diagnostics of mental disorders, which are accompanied by a violation of its work.

2. To use the size of the hippocampus as one of the prognostic factors for the severity of the memory-associated disorders and the therapy progress.

3. We recommend researchers to carefully investigate the difference in the effect of various psychotherapies and pharmacotherapies on the hippocampus (especially on its neurogenesis) in order to determine exactly be able to say exactly which of the therapies is the most morphologically reasonable.

4. To investigate whether the increase in volume/neurogenesis of the hippocampus or its absence is associated with an effective memory improvement in therapy and what features of this connection in order to find out how significant the decrease in the hippocampal volume is for the memory functioning.

5. To use pathogenetically and morphologically based methods to improve the function of the hippocampus in the treatment of disorders that are accompanied by memory problems.

Thus, we believe that our recommendations will make a definite contribution to clinical neuroscience, as well as help to answer the problematic questions that remain after the analysis of the literature, such as the features of the hippocampal volume reduction and its influence on the memory function; the effect of various therapies on the hippocampal volume, its neurogenesis and on the elimination of specific memory disorders in various diseases. An equally important issue not covered in the article is the difference in the morphology and hippocampal changes in organic brain damage, such as Alzheimer's, with changes in mental disorders. It has not been described in the article how mnemonic techniques affect morphology and hippocampal function and whether their influence on memory correlates with their effect on morphology. We believe that knowledge about the hippocampus will be enriched by research (especially interdisciplinary) of these topics.

\section{References}

[1] Backus, A., Schoffelen, J., Szebényi, S., Hanslmayr, S., \& Doeller, C. (2016). Hippocampal-Prefrontal Theta Oscillations Support Memory Integration. Current Biology, 26(4), 450-457. doi: http://dx.doi. org/10.1016/j.cub.2015.12.048.

[2] Bekinschtein, P., Cammarota, M., Katche, C., Slipczuk, L., Rossato, J., \& Goldin, A., et al. (2008). BDNF is essential to promote persistence of long-term memory storage. Proceedings Of The National Academy Of Sciences, 105(7), 2711-2716. doi: 10.1073/pnas.0711863105.

[3] Bremner, J., Narayan, M., Anderson, E., Staib, L., Miller, H., \& Charney, D. (2000). Hippocampal Volume Reduction in Major Depression. American Journal Of Psychiatry, 157(1), 115-118. doi: 10.1176/ ajp.157.1.115.

[4] de Quervain, D., Schwabe, L., \& Roozendaal, B. (2016). Stress, glucocorticoids and memory: implications for treating fear-related disorders. Nature Reviews Neuroscience, 18(1), 7-19. doi: 10.1038/nrn.2016.155.

[5] Finsterwald, C., \& Alberini, C. (2014). Stress and glucocorticoid receptor-dependent mechanisms in long-term memory: From adaptive responses to psychopathologies. Neurobiology Of Learning And Memory, 112, 17-29. doi: 10.1016/j.nlm.2013.09.017.

[6] Irle, E., Ruhleder, M., Lange, C., Seidler-Brandler, U., Salzer, S., Dechent, P., et al. (2010). Reduced amygdalar and hippocampal size in adults with generalized social phobia. Journal Of Psychiatry And Neuroscience, 35(2), 126-131. doi: 10.1503/jpn.090041. 
[7] Jacobs, J., Miller, J., Lee, S., Coffey, T., Watrous, A., Sperling, M., et al. (2016). Direct Electrical Stimulation of the Human Entorhinal Region and Hippocampus Impairs Memory, Neuron, 92(5), 983-990. doi: 10.1016/j. neuron.2016.10.062

[8] Kim, K., Ekstrom, A., \& Tandon, N. (2016). A network approach for modulating memory processes via direct and indirect brain stimulation: Toward a causal approach for the neural basis of memory. Neurobiology Of Learning And Memory, 134, 162-177. http://dx.doi.org/10.1016/j. nIm.2016.04.001.

[9] Krogh, J., Rostrup, E., Thomsen, C., Elfving, B., Videbech, P., \& Nordentoft, M. (2014). The effect of exercise on hippocampal volume and neurotrophines in patients with major depression-A randomized clinical trial. Journal Of Affective Disorders, 165, 24-30. doi: 10.1016/j. jad.2014.04.041.

[10] Levy-Gigi, E., Szabo, C., Richter-Levin, G., \& Kéri, S. (2015). Reduced hippocampal volume is associated with overgeneralization of negative context in individuals with PTSD. Neuropsychology, 29(1), 151-161. doi: $10.1037 /$ neu0000131.

[11] Mahar, I., Bambico, F., Mechawar, N., \& Nobrega, J. (2014). Stress, serotonin, and hippocampal neurogenesis in relation to depression and antidepressant effects. Neuroscience \& Biobehavioral Reviews, 38, 173-192. doi: 10.1016/j.neubiorev.2013.11.009.

[12] Mello-Carpes, P., da Silva de Vargas, L., Gayer, M., Roehrs, R., \& Izquierdo, I. (2016). Hippocampal noradrenergic activation is necessary for object recognition memory consolidation and can promote BDNF increase and memory persistence. Neurobiology of Learning and Memory, 127, 84-92. doi: 10.1016/j.nlm.2015.11.014.

[13] Mello-Carpes, P., \& Izquierdo, I. (2013). The Nucleus of the Solitary Tract $\rightarrow$ NucleusParagigantocellularis $\rightarrow$ Locus Coeruleus $\rightarrow$ CA1 region of dorsal hippocampus pathway is important for consolidation of object recognition memory. Neurobiology of Learning and Memory, 100, 55-63. doi: 10.1016/j.nlm.2012.12.002.

[14] Moroni, F., Nobili, L., laria, G., Sartori, I., Marzano, C., Tempesta, D. et al. (2014). Hippocampal slow EEG frequencies during NREM sleep are involved in spatial memory consolidation in humans. Hippocampus, 24(10), 1157-1168. doi: 10.1002/hipo.22299.

[15] MorroneParfitt, G., Barbosa, Â., Campos, R., Koth, A., \& Barros, D. (2012). Moderate stress enhances memory persistence: Are adrenergic mechanisms involved? Behavioral Neuroscience, 126(5), 729-734. doi: 10.1037/a0029861.

[16] Nelson, M. \& Tumpap,A. (2016). Posttraumatic stress disorder symptom severity is associated with left hippocampal volume reduction: a meta-analytic study. CNS Spectrums, 1-10. doi: 10.1017/S1092852916000833.

[17] Okuyama, T., Kitamura, T., Roy, D., Itohara, S., \& Tonegawa, S. (2016) Ventral CA1 neurons store social memory. Science, 353(6307), 1536-1541. doi: 10.1126/science.aaf7003.

[18] Reinecke, A., Thilo, K., Filippini, N., Croft, A., \& Harmer, C. (2014). Predicting rapid response to cognitive-behavioural treatment for panic disorder: The role of hippocampus, insula, and dorsolateral prefrontal cortex. Behaviour Research And Therapy, 62, 120-128. doi: 10.1016/j.brat.2014.07.017.

[19] Robin, J., Hirshhorn, M., Rosenbaum, R., Winocur, G., Moscovitch, M. \& Grady, C. (2014). Functional connectivity of hippocampal and prefrontal networks during episodic and spatial memory based on real-world environments. Hippocampus, 25(1), 81-93. doi: 10.1002/hipo.22352.

[20] Rubin, M., Shvil, E., Papini, S., Chhetry, B., Helpman, L., Markowitz, J. et al. (2016). Greater hippocampal volume is associated with PTSD treatment response. Psychiatry Research: Neuroimaging, 252, 36-39. doi: 10.1016/j.pscychresns.2016.05.001.

[21] Schwabe, L., \& Wolf, O. (2013). Stress and multiple memory systems: from 'thinking' to 'doing'. Trends in Cognitive Sciences, 17(2), 60-68. doi: 10.1016/j.tics.2012.12.001.

[22] Scoville, W., \& Milner, B. (1957). Loss of recent memory after bilatera hippocampal lesions. Journal Of Neurology, Neurosurgery \& Psychiatry, 20(1), 11-21.

[23] Suthana, N., \& Fried, I. (2014). Deep brain stimulation for enhancement of learning and memory. Neuroimage, 85, 996-1002. doi: 10.1016/j. neuroimage.2013.07.066.

[24] Tanaka, K., Pevzner, A., Hamidi, A., Nakazawa, Y., Graham, J. \& Wiltgen, B. (2014). Cortical Representations Are Reinstated by the Hippocampus during Memory Retrieval. Neuron, 84(2), 347-354. doi: 10.1016/j.neuron.2014.09.037.

[25] van Rooij, S. Kennis, M. Sjouwerman, R., van den Heuvel, M., Kahn, R. \& Geuze, E. (2015). Smaller hippocampal volume as a vulnerability factor for the persistence of post-traumatic stress disorder. Psychological Medicine, 45(13), 2737-2746. doi: 10.1017/S0033291715000707.

[26] Zeidman, P., \& Maguire, E. (2016). Anterior hippocampus: the anatomy of perception, imagination and episodic memory. Nature Reviews Neuroscience, 17(3), 173-182. doi: 10.1038/nrn.2015.24.

[27] Zoladz, P., \& Diamond, D. (2016). Psychosocial predator stress model of PTSD based on clinically relevant risk factors for trauma-induced psychopathology. In J. Bremner, Posttraumatic Stress Disorder: From Neurobiology to Treatment (pp. 125-143). New York: John Wiley \& Sons, Inc.

\section{Information about the authors:}

Assonov D. O., Student, Bogomolets National Medical University, Kyiv, Ukraine.

Bozhuk B. S., MD, PhD, Associate Professor, Department of General and Medical Psychology and Pedagogy of the Bogomolets National Medical University, Kyiv, Ukraine.

\section{Відомості про авторів:}

Ассонов А. О., студент, Національний меАичний університет імені О. О. Богомольця, м. Київ, Україна.

Божук Б. С., канА. меА. наук, доцент каф. загальної та медичної психології та педагогіки, Національний медичний університет імені О. О. Богомольця, м. Київ, Україна.

\section{Сведения об авторах:}

Ассонов А. А., студент, Национальный медицинский университет имени А. А. Богомольца, г. Киев, Украина.

Божук Б. С., канА. меА. наук, Аоцент каф. общей и медицинской психологии и педагогики, Национальный медицинский университет имени А. А. Богомольца, г. Киев, Украина.

Конфмікт інтересів: віАсутній.

Conflicts of Interest: authors have no conflict of interest to declare.

НаАійшло Ао редакції / Received: 06.06.2017

Після Аоопрацювання / Revised: 12.06.2017

Прийнято Ао Аруку / Accepted: 08.09.2017 